\title{
TREE-RING BASED RECORD OF INTRA-ERUPTIVE LAHAR ACTIVITY: AXALTZINTLE VALLEY, MALINCHE VOLCANO, MEXICO
}

\author{
OSVALDO FRANCO-RAMOS ${ }^{1,2}$, MARKUS STOFFEL ${ }^{3,4}$ and LORENZO VÁZQUEZ-SELEM ${ }^{2}$ \\ ${ }^{1}$ Instituto de Geografia. Universidad Nacional Autónoma de México, \\ Ciudad Universitaria Coyoacán, 04510, México \\ ${ }^{2}$ Instituto de Geografia. Universidad Nacional Autónoma de México, Ciudad Universitaria Coyoacán, 04510, México \\ ${ }^{3}$ Dendrolab.ch. Institute of Geological Sciences, University of Bern, Baltzerstr. 1+3, CH-3012 Bern, Switzerland \\ ${ }^{4}$ Climate Change and Impacts, Institute of Environmental Sciences, University of Geneva, \\ 7 route de Drize, $\mathrm{CH}-1227$ Carouge, Switzerland
}

\begin{abstract}
Lahars are a widespread phenomenon in volcanic environments and good knowledge generally exists on contemporary, syn-eruptive lahar activity. Much less data is, by contrast, available on post-eruptive lahars and/or hydrogeomorphic processes out of extinct volcanic complexes. In this study we present a reconstruction of intra-eruptive lahar activity in Axaltzintle valley (Malinche volcano) using growth-ring records of 86 Abies religiosa trees. Based on the identification of 217 growth disturbances, field evidence and hydrological records we reconstruct a total of 19 lahars for the period 1945-2011. The reconstructed lahars were mostly triggered by moderate intensity, but persistent rainfalls with sums of at least $\sim 100 \mathrm{~mm}$. By contrast, the 1998 and 2005 lahars were presumably triggered by hurricane-induced torrential rainfalls with $>100 \mathrm{~mm}$ in three days.
\end{abstract}

Keywords: Malinche volcano, lahars, dendrogeomorphology, tree-ring analysis, Abies religiosa.

\section{INTRODUCTION}

Lahars are a widespread phenomenon in volcanic environments (Smith and Fritz, 1989; Vallance, 2005; Lavigne and Thouret, 2002) and consist of a mixture of weakly consolidated volcanic debris, rocks, wood, and water tumbling down at high velocities. Lahar are commonly triggered by heavy rainfalls, condensate gas coming from volcanoes, excessive water in pores, or glacial and snow meltdown, but have also been reported as a result of river erosion or dam overflowing (Scott et al., 2001; Vallance, 2000). The steepness of volcanoes and the existence of proximal fluvial landforms prevailing in

Corresponding author: O. Franco-Ramos e-mail: ofranco@igg.unam.mx vast areas of Central and South America facilitate lahar development, and have caused a multitude of disasters over the last few decades.

By way of example, considerable areas of Nicaragua and Honduras have been devastated by lahars triggered by the 1998 hurricane Mitch, claiming thousands of victims and causing enormous economic losses (Vallance $e t$ al., 2004; Guinau et al., 2007). Other, more localized lahars may have caused fewer victims, but also devastated entire villages on the slopes of or next to volcanoes. In 1963-1964, for instance, volcanic activity and related lahars of Irazu volcano (Costa Rica) devastated houses and roads, but also caused 20 deaths (Waldron, 1967). In Mexico, Chichón volcano was at the origin of yet another devastating event in 1982, which buried several villages and resulted in thousands of casualties (Macías et al., 2008). Many other volcanoes of the Transmexican Volcanic Belt have produced lahars in historic times, such as 
Popocatepetl or Colima volcanoes (Capra et al., 2004; Muñoz-Salinas et al., 2009; Bollschweiler et al., 2010; Franco-Ramos et al., 2013; Vazquez et al., 2014), but magnitudes remained much smaller in these cases and events did not claim any victims.

The different disasters listed above either occurred as a result of active volcanism (i.e. as syn-eruptive lahars) or after heavy downpours onto unconsolidated volcanic sediment but in the absence of volcanic activity (also referred to as post-eruptive lahars; Capra and Macías, 2002; Cortes et al., 2010). The latter can occur on active volcanoes but also on dormant or extinct complexes and even long time after the last explosive activity (Saucedo et al., 2010). Intra- and post-eruptive lahars are typically triggered by hydrometeorological events (Vallance et al., 2004; Saucedo et al., 2008; Worni et al., 2012; Capra et al., 2010); they are typically of small(er) magnitude but occur much more frequently (Vallance, 2000). On Merapi volcano, lahars have been reported to occur with average intensity of $\sim 40 \mathrm{~mm}$ of rainfall in $2 \mathrm{~h}$ (Lavigne and Thouret, 2002), whereas $15-20 \mathrm{~mm} / \mathrm{h}$ of rainfall has been identified as a critical threshold for Japanese volcanoes (Lavigne et al., 2000). In the case of Pinatubo, observations indicate the triggering of lahars with rainfall intensities of ca. $12 \mathrm{~mm}$ in 30 minutes (Newhall et al., 1997). In the case of Mexican volcanoes, recent observations at Colima volcano illustrate that $20 \mathrm{~mm}$ of stored rain water and maximum rainfall intensities of $95 \mathrm{~mm} \mathrm{~h}^{-1}$ might be sufficient to trigger lahars (Vazquez et al., 2014).

The slopes of subtropical volcanoes with sporadic volcanic activity are sometimes covered by woody vegetation. Provided that vegetation, and in particular perennial shrubs and trees, can establish at sufficient altitudes ( $\sim 4000 \mathrm{~m}$ a.s.1.), they will form annual increment rings and can subsequently be utilized for absolute dating purposes. Various examples exist of annually-resolved time series from subtropical, high-elevation locations in Central and South America which can be used for dendroecological and/or dendroclimatic purposes (Biondi et al., 2003; Stahle et al., 2000; Villanueva et al., 2010; Stoffel et al., 2011b).

More recently, tree-ring records from conifers growing on the slopes of Iztaccíhuatl, Popocatépetl, and Colima volcanoes have also been used to infer chronologies of past mass movement activity including rockfall (Stoffel et al., 2011b) and lahar (Bollschweiler et al., 2010; Franco-Ramos et al., 2013) histories. These studies are based on the seminal papers of Alestalo (1971) and Shroder (1978) describing the dendroecological reactions of trees to geomorphic disturbance (Stoffel and Corona, 2014) and forming the foundation of contemporary dendrogeomorphology (Stoffel and Bollschweiler, 2008; Stoffel et al., 2010; Butler and Stoffel, 2013). Dendrogeomorphic techniques have been used widely to reconstruct hydrogeomorphic process activity (Stoffel and Wilford, 2012; Ballesteros-Cánovas et al., 2015a). The past focus was clearly on debris flows in the European
Alps for which the frequency (Arbellay et al., 2010a, 2010b; Bollschweiler and Stoffel, 2010a), magnitudefrequency relationships (Stoffel, 2010; Schraml et al., 2013), spread and reach (Bollschweiler et al., 2007, 2008a; Stoffel, 2008; Bollschweiler and Stoffel, 2010b), regional patterns (Procter et al., 2012 Schraml et al., 2015), triggers (e.g., Lugon and Stoffel, 2010; Stoffel et al., 2011a; Schneuwly-Bollschweiler and Stoffel, 2012) and potential future evolutions (Stoffel and Beniston, 2006; Stoffel et al., 2014a, 2014b) have been documented in detail with tree-ring series.

More recently, research expanded to include time series of flash floods (Ruiz-Villanueva et al., 2010; Ballesteros et al., 2010a, Ballesteros-Cánovas et al., 2015a; Ruiz-Villanueva et al., 2013) and the assessment of peak discharge of Mediterranean floods (Ballesteros et al., 2010b, Ballesteros-Cánovas et al., 2015a, 2015b) in ungauged catchments. The knowledge gained and the approaches developed in these environments have recently been applied at high(er) elevation slopes of active volcanoes in the Transmexican Volcanic Belt to derive time series of larger, $20^{\text {th }}$ century lahar activity (Bollschweiler et al., 2010; Franco-Ramos et al., 2013), but not so far on dormant or extinct volcanoes where the occurrence of lahars will be driven exclusively by hydroclimatic triggers.

In this study, we therefore aim at reconstructing intraeruptive lahar activity at one of the largest stratovolcanoes in Central Mexico, La Malinche, by using growthring records of sacred fir trees (Abies religiosa). Based on the analysis of buried, tilted and injured trees growing on and within fluvial terraces of Axaltzintle valley, we (i) construct a lahar chronology for the $20^{\text {th }}$ century and (ii) analyze hydroclimatic triggers of intra-eruptive lahar events. We report data on 19 lahars covering the period 1945-2011 and identify moderate-intensity, but persistent rainfalls with sums of at least $100 \mathrm{~mm}$ as the most common trigger of past events.

\section{STUDY SITE}

La Malinche (4461 $\mathrm{m}$ a.s.1.; $19^{\circ} 14^{\prime} \mathrm{N}$; $98^{\circ} 00^{\prime} \mathrm{W}$ ) is an active, yet quiescent Quaternary stratovolcano of andesito-dacitic composition and located in the TransMexican Volcanic belt (Fig. 1). The volcanic complex is characterized by a long history of eruptive periods with repeated growth and collapse of domes and other volcanic structures. The most recent eruption occurred more than 3100 yr BP ago (Castro-Govea and Siebe, 2007).

Several glacial fluctuations in the late Pleistocene and Holocene have shaped La Malinche to leave steep slopes and distinctive glacial (moraines, rock glaciers, till deposits, glacier cirques, U-shaped valleys) and periglacial landforms (talus deposits, debris-flow channels and cones; Vazquez-Selem and Heine, 2011) on its presentday surface, preferably at altitudes comprised between 3000 and $4400 \mathrm{~m}$ a.s.1. In addition, and as a result of hydrogeomorphic processes, deep ravines have formed 


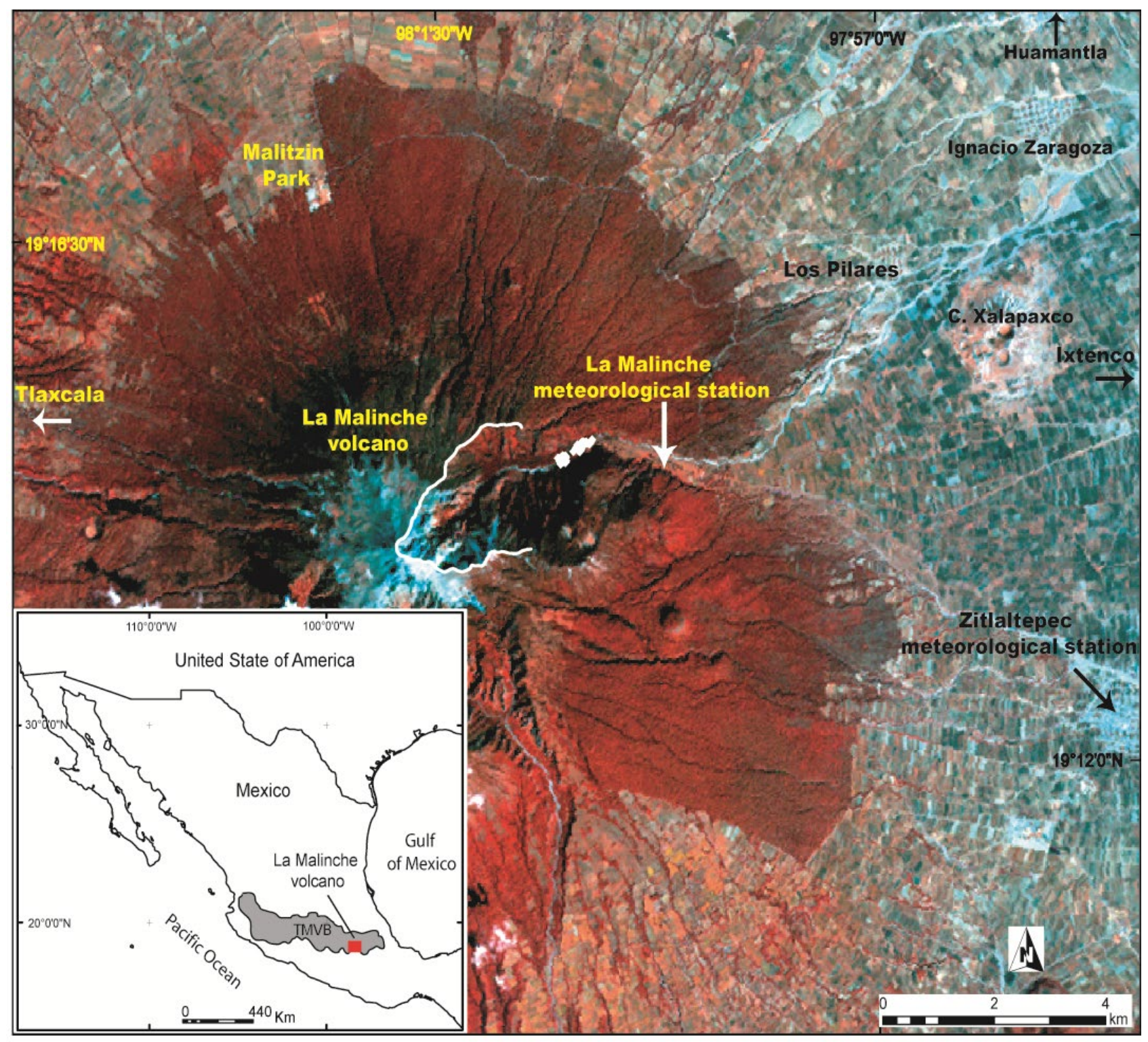

Fig. 1. La Malinche volcano is located in the central-eastern part of the Trans-Mexican Volcanic belt (TMVB). The Landsat satellite imagery in composite RGB false colors illustrates the forest cover of the volcano and Axaltzintle valley on its NE slopes (white line). The white dots indicate the sampling sites.

through the thick volcanoclastic cover of the mountain below $4000 \mathrm{~m}$ a.s.l.

Contemporary geomorphology and sediment transfer processes are somewhat, yet indirectly, determined by effects of the last two glacial advances in Central Mexico between 8300 to $7300 \mathrm{BP}$ and during the Little Ice Age (AD 1350-1850). These two episodes have mainly affected the periglacial zones of La Malinche and produced extensive scree slopes and debris-flow deposits (Vazquez-Selem and Heine, 2011; Castillo-Rodriguez et al., 2007). As a consequence, and for altitudes $>4000$ $\mathrm{m}$ a.s.l., the heritage as well as contemporary periglacial processes facilitate intense morphodynamic events such as rockfalls out of steep walls as well as debris flows in glacial valleys (Castillo-Rodriguez et al., 2007).

Axaltzintle, a U-shaped valley which has been carved into the NE slope of the volcano, is the largest erosive feature of La Malinche and characterized by the most active contemporary geomorphic activity. Its upper basin, which extends from 4400 to $3500 \mathrm{~m}$ a.s.l. $\left(4 \mathrm{~km}^{2}\right.$, mean slope angle $30^{\circ}$ ), favours the occurrence of erosion and runoff. The site is known as a source area of intraeruptive lahars - yet of unknown age and frequency which are drained by the mountain river to form a wide alluvial fan in its lower portion (Fig. 1). 
Inside Axaltzintle valley, three major geomorphic units can be identified below $3500 \mathrm{~m}$ a.s.l. (Fig. 2A), namely (i) an upper terrace (T-1) at the base of the valley slopes; it has a width and length of several dozens of meters and an average depth of 2 meters, consisting of at least 4 layers of lahar deposits. Individual layers are delimited by leaf litter, roots and fluvial deposits. Its morphology is tube-shaped with reasonably stable slopes of $2-5^{\circ}$ and made of fine and consolidated detritus $<60 \mathrm{~cm}$ in diameter topped by an emergent soil layer of $c a .15 \mathrm{~cm}$ and a thick and dense $A$. religiosa forest stand with individual trees being 100 or more years old (Fig. 2B); (ii) a lower terrace (T-2), smaller in dimension, irregular, just a few meters in width and length and with a thickness ranging from $50-100 \mathrm{~cm}$; it consists of at least 3 layers of lahar deposits separated by thin layers of fluvial material. Its morphology is flat and mainly formed by poorly consolidated detritus with mean diameters of $\sim 80 \mathrm{~cm}$ as well as ample amounts of impacted and buried young trees along the riverside (Fig. 2C); (iii) an active channel with the most recent deposits, mainly detritus, dead tree trunks and blocks with diameters generally $>1 \mathrm{~m}$ (Fig. 2C).

The study area is located at an altitude of around 3300 $\mathrm{m}$ a.s.l. in the Axaltzintle valley (Fig. 1). The site is colonized by a dense evergreen community of sacred firs ( $A$. religiosa) preferably growing on the steep and humid valley slopes (Rojas García, 2008). The A. religiosa growth rings are sensitive to climatic variations, and depend mainly on winter-spring precipitation (Huante et al., 1991; Cerano Paredes et al., 2014). Average annual
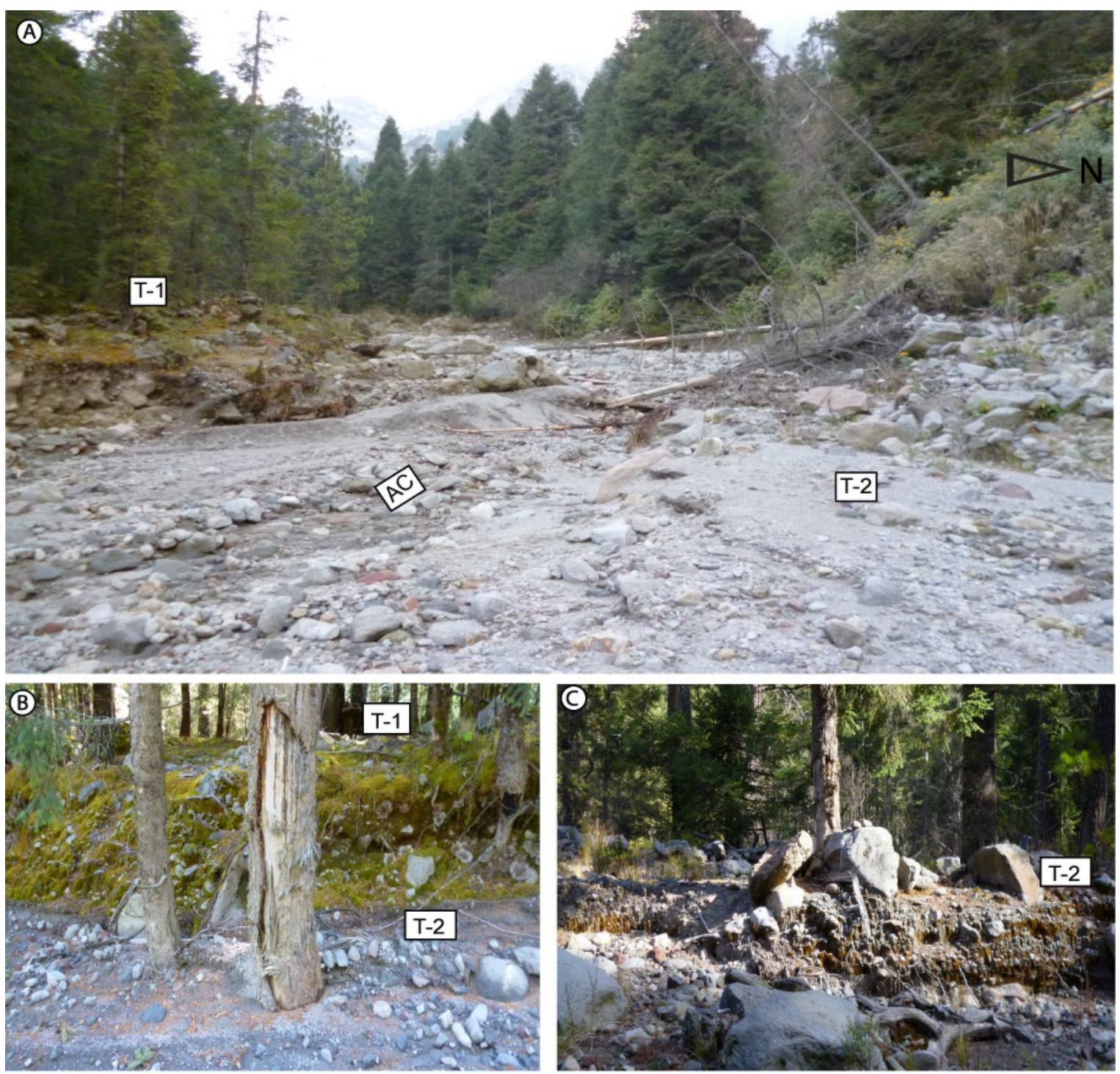

Fig. 2. A) Abies religiosa forest growing near the Axaltzintle valley bottom. B) Low terraces point to the deposition of lahar material in the valley whereas trees point to their recent occurrence via impact scars of up to $1 \mathrm{~m}$ on their stems. C) Trees buried and impacted by recent lahars. T-1: upper terrace. T-2: lower terrace. AC: active channel. 
rainfall (2006-2013) at La Malinche Research Centre ( $\sim 3140 \mathrm{~m}$ a.s.l.) is $460 \mathrm{~mm}$, with most rain falling between June and September. In 1998-1999, the late arrival of excessive humidity produced torrential rainfalls in September 14-16 of 1998 resulting in $136 \mathrm{~mm}$ of precipitation recorded at Zitlaltepec station (CNA-SMN, 2013).

\section{METHODS}

The study presented here is based on the analysis of mechanical disturbances in $A$. religiosa induced by intraeruptive lahars. The species has been used in the past in dendroecological research and has proven suitable for cross dating and sensitive to climate (Huante et al., 1991; Bollschweiler et al., 2010; Cerano Paredes et al., 2014).

In the field, trees with clear evidence of lahar damage were selected and sampled with an increment borer. The focus was on trees with stem bases buried in lahar material, trunks with visible injuries inflicted by lahars as well as on trees tilted by the forces of passing lahars. Sampling was focused on trees growing within terraces T-1 and T-2 as well as on vegetation on the gravel bars within the inner channel; it included a total of $86 \mathrm{~A}$. religiosa trees from which 157 increment cores (Fig. 3A), 6 wedges, and 5 cross-sections (Fig. 3B) were extracted for a total of 168 samples (Table $\mathbf{1}$ ).

In the laboratory, samples were analyzed following the standard procedures described in Stoffel and Bollschweiler (2008) and Stoffel and Corona (2014). Individual working steps included the sanding of increment cores and measurement of tree-ring widths using a LINTAB measuring device and TSAPWin software (Rinntech, 2012). Growth curves of disturbed trees were then crossdated with a reference chronology — built with
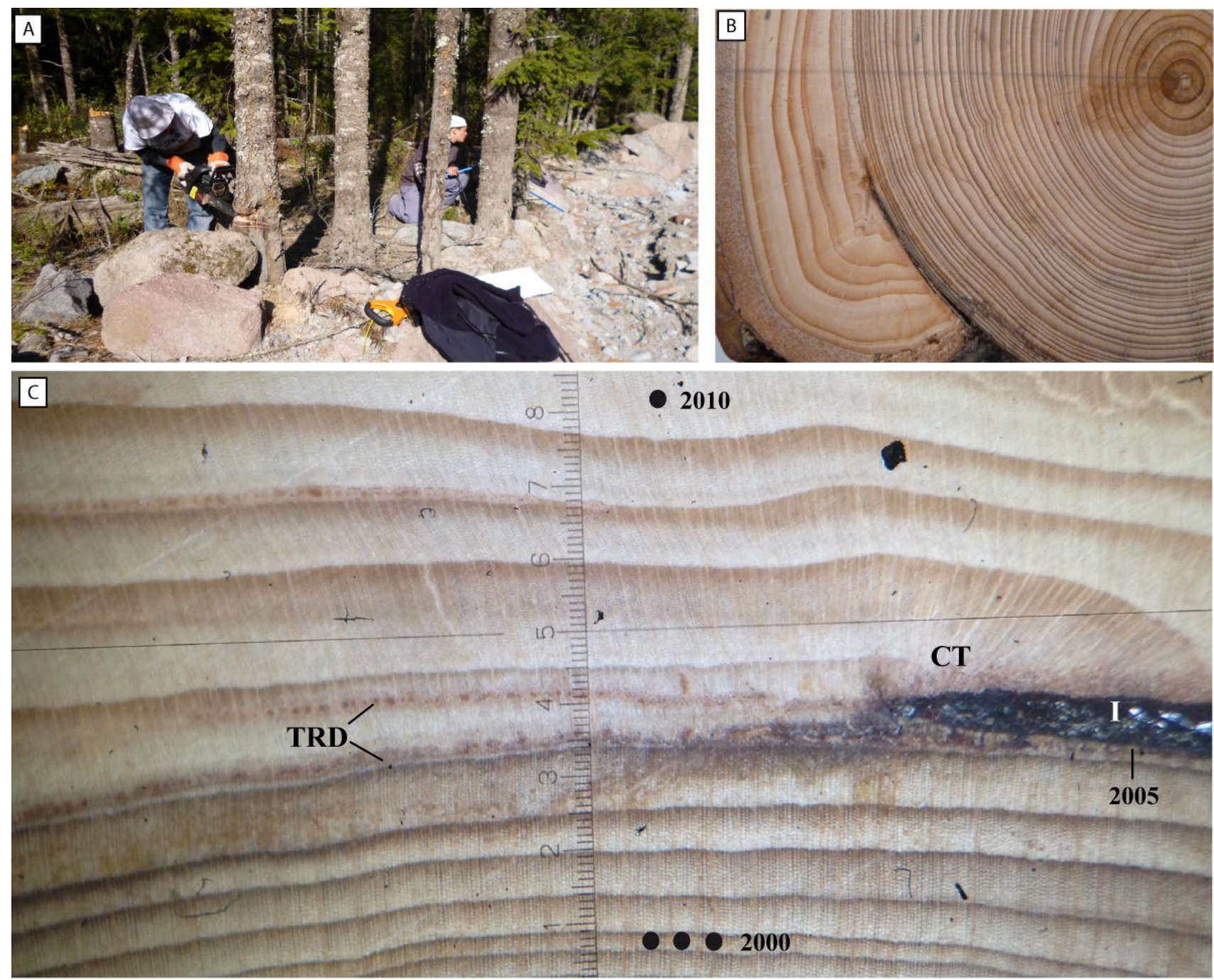

Fig. 3. A) Living trees affected by lahars in general were sampled with increment cores. B) Partial cross sections were taken from a limited number of impact scars. C) Detailed views of different types of growth disturbances in Abies religiosa caused by lahars: injury (I), callus tissue (CT) and tangential rows of traumatic resin ducts (TRD). 
Table 1. Spatial distribution and type of samples in the Axaltzintle valley.

\begin{tabular}{lcccc}
\hline & T-1 & T2 & $\begin{array}{c}\text { Inside of } \\
\text { chanel }\end{array}$ & Total \\
\hline $\begin{array}{l}\text { Tree samples in } \\
\text { A. religiosa }\end{array}$ & 56 & 21 & 9 & 86 \\
\hline Increment cores & 111 & 35 & 11 & 157 \\
Cross sections & 1 & 3 & 1 & 5 \\
Wedges & 1 & 1 & 4 & 6 \\
\hline Total & 113 & 39 & 16 & 168 \\
\hline
\end{tabular}

trees growing in the same area but unaffected by lahars - so as to identify missing or faulty tree rings. This reference chronology also helped the differentiation of climatically induced fluctuations in tree growth from growth anomalies caused by lahars.

In $A$. religiosa, the main growth disturbance (or GD) related to lahars was in the form of wounds (scars) on the stem surface and the corresponding callus tissue and tangential rows of traumatic resin ducts (or TRD) in the tree-ring records (Fig. 3C). The occurrence of TRDs in tree-ring records (Stoffel, 2008) has been demonstrated to be one of the most reliable and exact markers of past geomorphic disturbance and has thus been used extensively in the European Alps to reconstruct geomorphic events (Bollschweiler et al., 2008a, 2008b; Stoffel and Hitz, 2008; Schneuwly et al., 2009a, 2009b; Stoffel et al., 2014b). The potential of $A$. religiosa to record lahars and to record events through the formation of TRDs has been demonstrated earlier by Bollschweiler et al. (2010). In addition to TRDs, this study also focused on the initiation of abrupt growth suppression (Kogelnig-Mayer et al., 2011) and release (Stoffel and Bollschweiler, 2008). In the case of tilted stems, both the appearance of compression wood cells as well as the ring-width series were analyzed (Braam et al., 1987a, 1987b; Šilhán and Stoffel, 2015) to date the moment of stem tilting and related compression wood occurrence in trees.

All records of GD in trees were then dated and the intensity of individual responses to lahars evaluated based on the criteria defined in Kogelnig-Mayer et al. (2011) and Stoffel and Corona (2014). In a last analytical step we compared years with reconstructed lahars with the rainfall data from the nearby meteorological stations Zitlaltepec (2370 m a.s.l.; 1966-2005), Huamantla (2485 m a.s.1.; 1945-2005; CNA-SMN, 2013) and the most recent rainfall data from La Malinche station (unpublished).

\section{RESULTS}

The sacred firs (A. religiosa) investigated in this study exhibit an average age at sampling height of 49 years (STDEV: 16), which limits the length of the lahar reconstruction to the past few decades. The oldest tree has increment rings going back to $\mathrm{AD} 1916$, whereas the youngest tree selected for analyses attained breast height in AD 1991. Based on the age structure of the trees sampled, a period of intense tree colonization can be observed in the early 1940s, when more than half of the sampled trees $(60 \%)$ started to colonize the study site. The oldest trees are growing on terrace $\mathrm{T}-1$, whereas trees started to colonize terrace T-2 and the less active portions of the present-day channel in AD 1937 and 1944, respectively.

The 86 trees sampled for analysis provided evidence of 217 GD related to past lahar activity. Based on these records, TRDs form the most common reaction to lahar impact and wounding with $48 \%$, followed by the sudden suppression of growth (30\%) reflecting stem burial and or root damage. Injuries (and related callus tissue) were primarily detected indirectly (i.e. through the presence of TRDs on the increment cores) and only declared as such if found on cross-sections (11\%). Eccentric growth and related compression wood, reflecting stem tilting events, were relatively scarce with 5 and $3 \%$, respectively, whereas growth releases due to the elimination of neighboring trees were almost completely absent in the dataset with only $2 \%$ (Table 2 ).

The spatial patterns of disturbances occurring simultaneously in several trees were then used to filter noise from signal and to determine lahar events causing abundant damage to trees in the channel segments analyzed in this study. Fig. 4 illustrates that a total of 19 intraeruptive lahars can be inferred from the tree-ring records. Fourteen of these events left abundant evidence in a large number of trees $(>7 \mathrm{GDs})$. These events were dated to AD 1970, 1971, 1975, 1980, 1984, 1986, 1990, 1992, 1994, 1998, 2000, 2001, 2003, and 2005. In the case of the other five lahars, less anomalies could be found in trees (2-5 GDs), either as a result of decreasing sample size, unfavorable channel conditions (e.g., channel incision with no or only overbank sedimentation), or limited event size. Nevertheless, enough evidence exists for the following years to be considered years with possible lahar activity: AD 1945, 1952, 1962, 1967, and 2011.

The GD used in each tree for lahar reconstructions as well as the chronology of reconstructed lahars is presented in Fig. 4. Solid lines correspond to years for which a

Table 2. Number and percentage of growth disturbances (GD) induced by lahars as reconstructed from the tree-ring records of Abies religiosa in the Axaltzintle valley.

\begin{tabular}{lcc}
\hline GDs of A. religiosa & No. & $\%$ \\
\hline TRD & 105 & 48 \\
Growth suppression & 66 & 30 \\
Injury & 22 & 10 \\
Eccentric growth & 11 & 5 \\
Compression wood & 6 & 3 \\
Growth release & 5 & 2 \\
Callus tissue & 2 & 1 \\
\hline Total & 217 & 100 \\
\hline
\end{tabular}




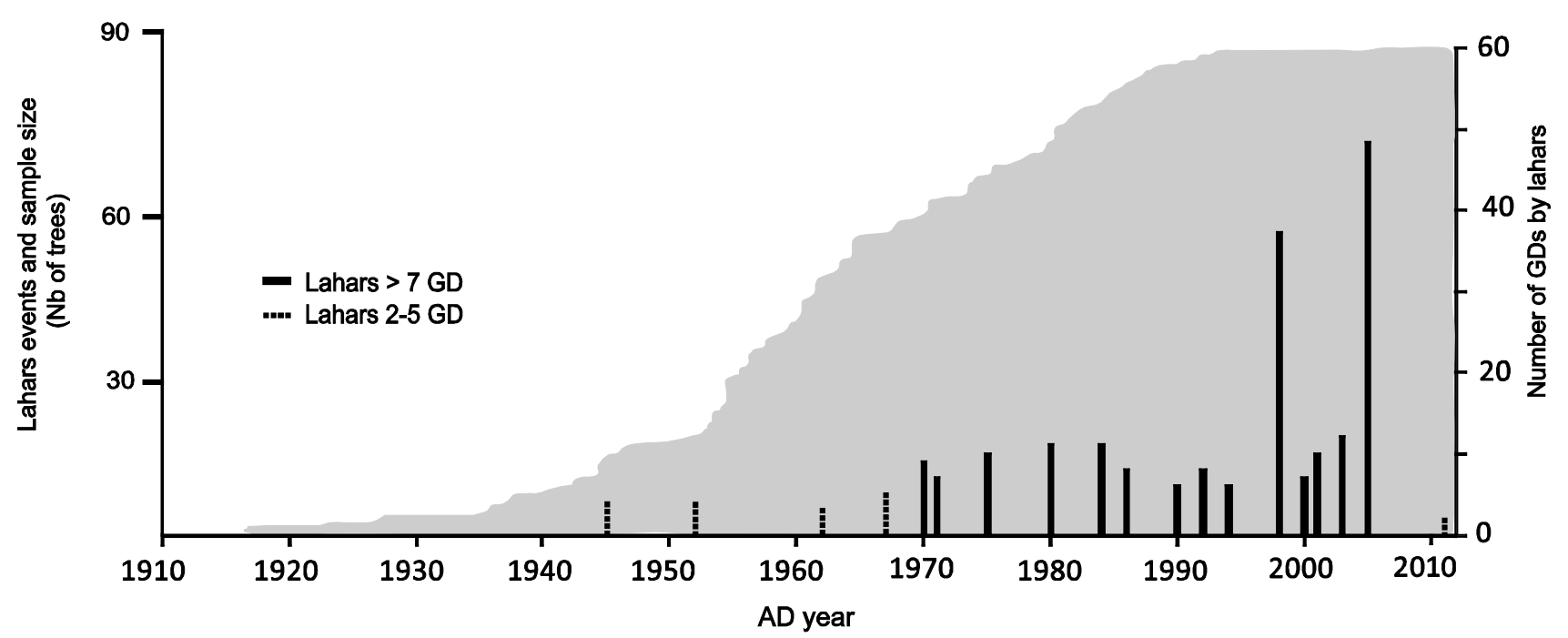

Fig. 4. Evidence of lahar activity as identified in the trees sampled in the different geomorphic units of Axaltzintle valley. Solid lines are lahars reconstructed with >7 growth disturbances (GD); dashed lines stand for events with 2-5 disturbances. The 19 lines correspond to lahars in the final reconstruction.

large body of evidence exists for the events to be dated; dashed lines indicate those years for which the amount or intensity of reactions in trees was substantial yet less abundant than in other years.

Among the lahars reconstructed, the events of 1998 and 2005 have left by far the largest fingerprint in the main channel as well as on the higher terrace (T-2), leaving severe damage - mostly in the form of impact scars, TRD and abrupt growth suppression — in a vast majority of the tress selected for analysis (72\%). The two events and the surfaces affected by the lahars - given via the distribution of affected trees - are shown in Fig. 5.

\section{DISCUSSION}

In the study we report here, the spatial and temporal occurrence of intra-eruptive lahars has been reconstructed for Axaltzintle valley, La Malinche volcano, Mexico. Based on the analysis of tree-ring records from $86 \mathrm{~A}$. religiosa trees, we document 217 GDs related to the occurrence of past lahars, and thereby demonstrate the potential of the species for dendrogeomorphic purposes. As typical for Abies - at least for European species for which a larger series of studies exists (Stoffel, 2008) tangential rows of traumatic resin ducts forming around wounds form the most frequent, but also the most obvious line of evidence for the occurrence of past mechanical disturbances. TRDs have been used in one case out of two $(48 \%)$ to date lahars and thus corroborate the findings of Bollschweiler et al. (2010) who described this feature as key in their study of syn- and post-eruptive lahars on the slopes of Popocatepetl volcano.
We also contrasted maximum 3-day precipitation totals with the time series of reconstructed lahars. In the absence of any knowledge of the exact timing of lahar occurrence, however, such a comparison is not conclusive, even more so in the case where local precipitation effects (i.e. orographic rainfalls) are unlikely to be captured by meteorological stations located several (dozens of) kilometers away from the source area of lahars (Stoffel et al., 2011a; Schneuwly-Bollschweiler and Stoffel, 2012; Franco-Ramos et al., 2013). Torrential rainfalls on October 4-6 1999 resulted in several landslides and debris flows processes in the Sierra Norte de Puebla with rainfall of up to $800 \mathrm{~mm}$, triggered by a tropical depression in the Gulf of México (Lugo-Hubp et al., 2005; Capra et al., 2006). Dates from the Zitlaltepec meteorological station pointto roughly $100 \mathrm{~mm}$ of precipitation at the study site (CNA-SMN, 2013). Tree-ring data does not point to any lahar activity in 1999, presumably because of the much smaller rainfall totals recorded at our study site as compared to other regions of Mexico.

In the case of the presumably important lahars of 1998 and 2005, which affected a majority of all sampled trees each (Fig. 5), the occurrence of events coincides with the passage of hurricanes and related heavy rainfalls (NOAA, 2015). At Zitlaltepec station (CNA-SMN, 2013) located $\sim 10 \mathrm{~km}$ away from the source area of 1998 lahar, recorded $\sim 140 \mathrm{~mm}$ of rainfall over a period of three days. The 2005 lahar was presumably triggered by a heavy rainfall event ( $>100 \mathrm{~mm}$ in three days) in the area between August 29 and 31 (Zitlaltepec station (CNA-SMN, 2013). 


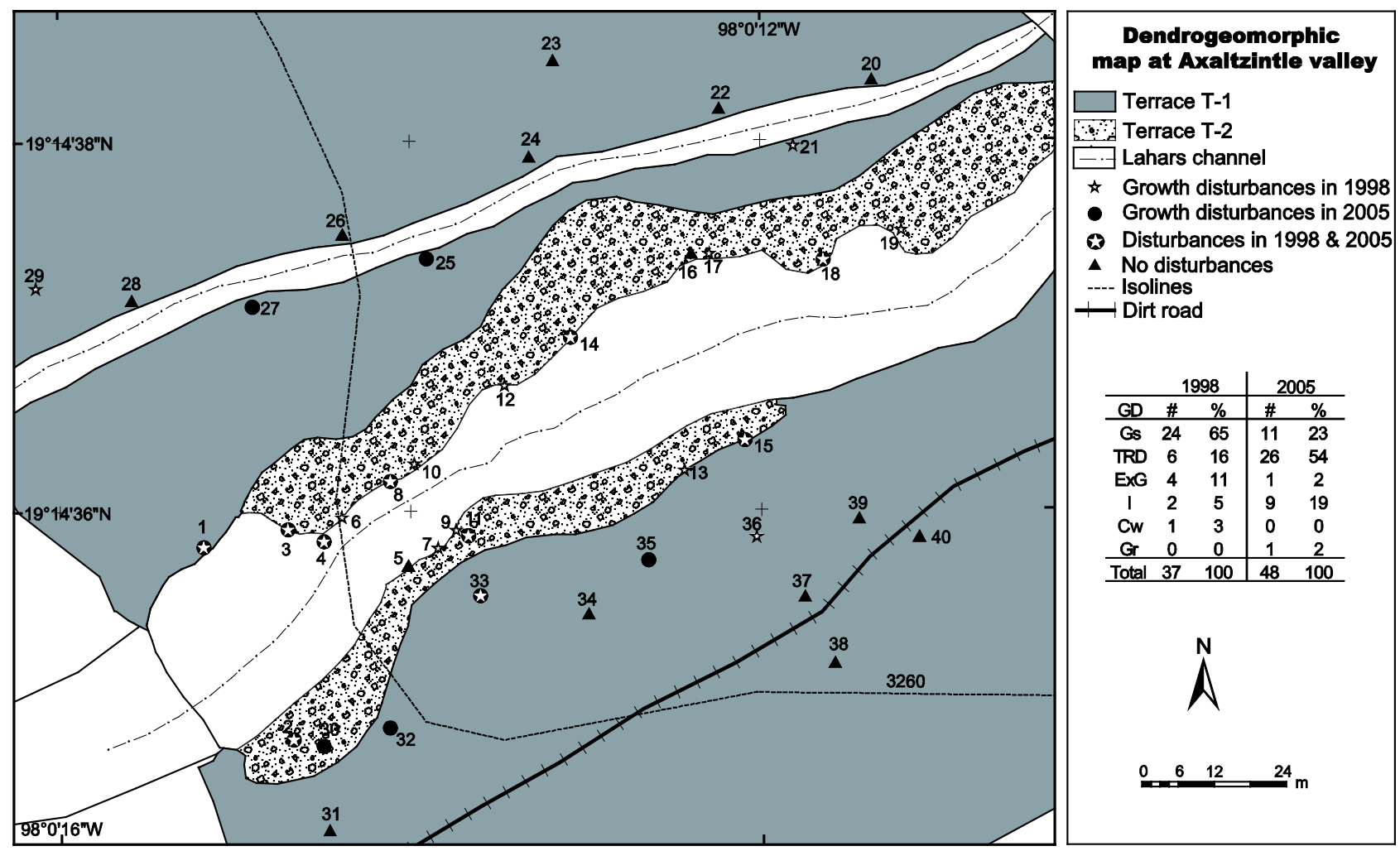

Fig. 5. Trees affected by the 1998 and 2005 lahars. Gs = growth suppression, $T R D=$ tangential rows of traumatic resin ducts, ExG $=$ eccentric growth, I = injury, $\mathrm{Cw}=$ compression wood; and $\mathrm{Gr}=$ growth release. For details see text.

Still, the number and intensity of GD detected in the tree-ring records is much smaller than in the other cases, and points to a (i) possibly smaller overall magnitude of these lahars (e.g., dilute flows), (ii) more important incision of the channel (and thus a larger cross-section) prior to lahar occurrence or a (iii) flow path for which trees do not exist anymore today.

\section{CONCLUSIONS}

The present research provides a record of intraeruptive lahar activity using dendrogeomorphic methods and the number and intensity of GDs recorded in the treering series of impacted $A$. religiosa. We assume that past lahar activity at Axaltzintle was preferably triggered by intense hydrometeorological events (hurricanes) and prolonged rainfall as was the case in 1998 and 2005. The promising results of this first documentation of intraeruptive lahars on volcanoes without eruptive activity of the Transmexican Volcanic Belt, calls for more and more extensive reconstructions including a greater number of trees sampled from more areas within the valley or in other basins of La Malinche.

\section{ACKNOWLEDGMENT}

The authors kindly acknowledge Michelle Schneuwly-Bollschweiler and Daniel Trappmann for their support during sample analysis and signal interpretation. Funding was provided by DGAPA-PAPIIT project IN1052133. Osvaldo Franco Ramos benefitted from a CONACYT doctoral fellowship.

\section{REFERENCES}

Alestalo J, 1971. Dendrochronological interpretation of geomorphic processes. Fennia 105: 1-139.

Arbellay E, Stoffel M and Bollschweiler M, 2010a. Wood anatomical analysis of Alnus incana and Betula pendula injured by a debrisflow event. Tree Physiology 30: 1290-1298, DOI 10.1093/treephys/tpq065.

Arbellay E, Stoffel M and Bollschweiler M, 2010b. Dendrogeomorphic reconstruction of past debris-flow activity using injured broadleaved trees. Earth Surface Processes and Landforms 35: 399-406, DOI 10.1002/esp.1934.

Ballesteros JA, Stoffel M, Bodoque del Pozo JM, Bollschweiler M, Hitz $\mathrm{OM}$ and Diez-Herrero A, 2010b. Changes in wood anatomy in tree rings of Pinus pinaster Ait. following wounding by flash floods. Tree-Ring Research 66: 93-103, DOI 10.3959/2009-4.1.

Ballesteros JA, Stoffel M, Bollschweiler M, Bodoque del Pozo JM and Díez-Herrero A, 2010a. Flash-flood impacts cause changes in wood anatomy of Alnus glutinosa, Fraxinus angustifolia and Quercus pyrenaica. Tree Physiology 30: 773-781, DOI 10.1093/treephys/tpq031. 
Ballesteros-Cánovas JA, Rodríguez-Morata, C, Garófano-Gómez V, Rubiales JM, Sánchez-Salguero R and Stoffel M, 2015a. Unravelling past flash floods activity in a forested mountain catchment of the Spanish Central System. Journal of Hydrology 529: 468-479, DOI 10.1016/j.jhydrol.2014.11.027.

Ballesteros-Cánovas JA, Márquez-Peñaranda JF, Sánchez-Silva M, Díez-Herrero A, Ruiz-Villanueva V, Bodoque JM and Stoffel M, 2015b. Can tree tilting be used for paleoflood discharge estimations? Journal of Hydrology 529: 480-489, DOI 10.1016/j.jhydrol.2014.10.026.

Biondi F, Galindo I, Gavilanes JC and Elizalde A, 2003. Tree growth response to the 1913 eruption of Volcan de Fuego de Colima, Mexico. Quaternary Research 59: 293-299, DOI 10.1016/S00335894(03)00034-6.

Bollschweiler M, Stoffel M, Ehmisch M and Monbaron M, 2007. Reconstructing spatio-temporal patterns of debris flow activity using dendrogeomorphological methods. Geomorphology 87: $337-$ 351, DOI 10.1016/j.geomorph.2006.10.002.

Bollschweiler M, Stoffel M and Schneuwly D, 2008a. Dynamics in debris-flow activity on a forested cone- A case study using different dendroecological approaches. Catena 72: 67-78, DOI 10.1016/j.catena.2007.04.004.

Bollschweiler M, Stoffel M, Schneuwly D, 2008b. Traumatic resin ducts in Larix decidua stems impacted by debris flows. Tree Physiology 28: 255-263, DOI 10.1093/treephys/28.2.255.

Bollschweiler M, Stoffel M, Vázquez-Selem L and Palacios D, 2010. Tree-ring reconstruction of past lahar activity at Popocatépetl volcano, México. The Holocene 20(2): 265-274, DOI $10.1177 / 0959683609350394$.

Bollschweiler M and Stoffel M, 2010a. Tree rings and debris flows: recent developments, future directions. Progress in Physical Geography 34: 625-645, DOI 10.1177/0309133310370283.

Bollschweiler M and Stoffel M, 2010b. Changes and trends in debrisflow frequency since $\mathrm{AD} 1850$ : Results from the Swiss Alps. The Holocene 20: 907-916, DOI 10.1177/0959683610365942.

Braam RR, Weiss EEJ and Burrough PA, 1987b. Dendrogeomorphological analysis of mass movement; a technical note on the research method. Catena 14: 585-589, DOI 10.1016/0341-8162(87)90008-7.

Braam RR, Weiss EEJ and Burrough PA, 1987a. Spatial and temporal analysis of mass movement using dendrochronology. Catena 14: 573-584, DOI 10.1016/0341-8162(87)90007-5.

Butler DR and Stoffel M, 2013. John F. Shroder, Jr.'s 1978 and 1980 papers on dendrogeomorphology. Progress in Physical Geography 37(5): 717-721, DOI 10.1177/0309133313501107.

Capra L and Macías JL, 2002. The cohesive Naranjo debris flow deposit $\left(10 \mathrm{~km}^{3}\right)$ : a dam breakout flow derived from the pleistocene debris-avalanche deposit of Nevado de Colima volcano (Mexico). Journal of Volcanology and Geothermal Research 117: 213-235, DOI 10.1016/S0377-0273(02)00245-7.

Capra L, Borselli L, Varley N, Gavilanes-Ruiz JC, Norini G, Sarocchi D, Caballero L and Cortes A, 2010. Rainfall-triggered lahars at Volcán de Colima, Mexico: Surface hydro-repellency as initiation process. Journal of Volcanology and Geothermal Research 189: 105-117, DOI 10.1016/j.jvolgeores.2009.10.014.

Capra L, Poblete MA and Alvarado R, 2004. The 1997 and 2001 lahars of Popocatépetl volcano (Central Mexico): textural and sedimentological constraints on their origin and hazards. Journal of Volcanology and Geothermal Research 131: 351-369, DOI 10.1016/S0377-0273(03)00413-X.

Capra L, Lugo-Hubp J and Zamorano-Orózco JJ, 2006. La importancia de la geología en el estudio de los procesos de remoción en masa: el caso de Totomoxtla, Sierra Norte de Puebla, México. Boletín de la Sociedad Geológica Mexicana Tomo LVIII, Núm. 2: 205-214.

Castillo-Rodríguez M, López-Blanco J and Palacios D, 2007. Multivariate analysis of the location of rock glaciers and the environmental implications in a tropical volcano: La Malinche (Central Mexico). Zeitschrift für Geomorphologie $N . \quad F$. 51: 39-54, DOI 10.1127/0372-8854/2007/0051S2-0039.

Castro-Govea R and Siebe C, 2007. Late-Pleistocene-Holocene stratigraphy and radiocarbon dating of La Malinche volcano, Central
Mexico. Journal of Volcanology and Geothermal Research 162: 20-42, DOI 10.1016/j.jvolgeores.2007.01.002.

Cerano Paredes J, Villanueva Díaz J, Cervantes-Martínez R, VázquezSelem L, Trucios-Caciano R and Guerra de la Cruz V, 2014. Reconstrucción de precipitación invierno-primavera para el Parque Nacional Pico de Tancítaro, Michoacán. Investigaciones Geográficas, Boletín del Instituto de Geografia 83: 41-54, DOI 10.14350/rig.35190.

CNA-SMN, 2013. Archivo de datos climatológicos del Servicio Meteorológico Nacional. www.smn.cna.gob.mx

Cortes A, Macías JL, Capra L and Garduño-Monroy VH, 2010. Sector collapse of the SW flank of Volcán de Colima, México. The 3600 yr BP La Lumbre-Los Ganchos debris avalanche and associated debris flows. Journal of Volcanology and Geothermal Research 197(1-4): 52-66, DOI 10.1016/j.jvolgeores.2009.11.013.

Franco-Ramos O, Stoffel M, Vázquez-Selem L and Capra L, 2013. Spatio-temporal reconstruction of lahars on the southern slopes of Colima volcano, Mexico - A dendrogeomorphic approach. Journal of Volcanology and Geothermal Research 267: 30-38, DOI 10.1016/j.jvolgeores.2013.09.011.

Guinau M, Vilajosana I and Vilaplana JM, 2007. GIS-based debris flow source and runout susceptibility assessment from DEM data- a case study in NW Nicaragua. Natural Hazards Earth System Sciences 7: 703-716.

Huante P, Rincon E and Swetnam T, 1991. Dendrochronology of Abies religiosa in Michoacan, Mexico. Tree-Ring Bulletin 51: 15-28.

Kogelnig-Mayer B, Stoffel M, Schneuwly-Bollschweiler M, Hübl J and Rudolf-Miklau F, 2011. Possibilities and limitations of dendrogeomorphic time-series reconstructions on site influenced by debris flows and frequent snow avalanche activity. Artic, Antarctic and Alpine Research 43(4): 649-658, DOI 10.1657/1938-424643.4.649.

Lavigne F and Thouret JC, 2002. Sediment transportation and deposition by rain-triggered lahars at Merapi Volcano, Central Java, Indonesia. Geomorphology 49: 45-69, DOI 10.1016/S0169555X(02)00160-5.

Lavigne F, Thouret JC, Voight B, Suwa H and Sumaryono A, 2000. Lahars at Merapi volcano, Central Java: an overview. Journal of Volcanology and Geothermal Research 100: 423-456, DOI 10.1016/S0377-0273(00)00150-5.

Lugon R and Stoffel M, 2010. Rock-glacier dynamics and magnitudefrequency relations of debris flows in a high-elevation watershed: Ritigraben, Swiss Alps. Global and Planetary Change 73: 202210, DOI 10.1016/j.gloplacha.2010.06.004.

Lugo-Hubp J, Zamorano-Orozco JJ, Capra L, Inbar M and AlcántaraAyala I, 2005. Los procesos de remoción en masa en la Sierra Norte de Puebla, octubre de 1999: Causa y efectos. (Mass movements processes at Sierra Norte de Puebla in October, 1999: triggers and effects) Revista Mexicana de Ciencias Geológicas 22(2): 212-228. (In Spanish)

Macías JL, Capra L, Arce JL, Espíndola JM, García-Palomo A and Sheridan MF, 2008. Hazard map of Chichón volcano, Chiapas, México: Constraints posed by eruptive history and computer simulations. Journal of Volcanology and Geothermal Research 175: 444-458, DOI 10.1016/j.jvolgeores.2008.02.023.

Muñoz-Salinas E, Castillo-Rodríguez M, Manea V, Manea M and Palacios D, 2009. Lahar flow simulation using LAHARZ program: Application for Popocatépetl volcano, Mexico. Journal of Volcanology and Geothermal Research 182: 13-22, DOI 10.1016/j.jvolgeores.2009.01.030.

Newhall C, Stauffer PH and Hendley JW, 1997. Lahars of Mount Pinatubo, Philippines. U. S. Geoogical Survey Fact Sheet 114.

NOAA, 2015. Historical Hurricane Track NOAA database, accesses 2013 (http://csc.noaa.gov/hurricanes/\#).

Procter E, Stoffel M, Bollschweiler M and Neumann M, 2012. Exploring debris-flow history and process dynamics using an integrative approach on a dolomitic cone in western Austria. Earth Surface Processes and Landforms 37: 913-922, DOI 10.1002/esp.3207.

Rinntech, 2012. LINTAB-Precision Ring by Ring. http://www.rinntech.com/Products/Lintab.htm. (accessed June 2012). 
Rojas García F, 2008. Consideraciones para el balance de carbono: evauación del movimiento de biomasa en el Parque Nacional Malinche. Tesis de Maestria (Considerations on the carbonbalance: assessment of the movement of biomass at Malinche National Park. Master thesis), Posgrado de Ciencias Biológicas, UNAM. pp. 70. (In Spanish)

Ruiz-Villanueva V, Díez-Herrero A, Bodoque JM, Ballesteros JA and Stoffel M, 2013. Characterization of flash floods in small ungauged mountain basins of central Spain using an integrated approach. Catena 110: 32-43, DOI 10.1016/j.catena.2013.06.015.

Ruiz-Villanueva V, Diez-Herrero A, Stoffel M, Bollschweiler M, Bodoque JM and Ballesteros JA, 2010. Dendrogeomorphic analysis of flash floods in a small ungauged mountain catchment (Central Spain). Geomorphology 118: 383-392, 10.1016/j.geomorph.2010.02.006.

Saucedo R, Macías JL, Gavilanes JC, Arce JL, Komorowski JC, Gardner JE and Valdez-Moreno G, 2010. Eyewitness, stratigraphy, chemistry, and eruptive dynamics of the 1913 Plinian eruption of Volcán de Colima, México. Journal of Volcanology and Geothermal Research 191(3-4): 149-166, DOI 10.1016/j.jvolgeores.2010.01.011.

Saucedo R, Macías JL, Sarocchi D, Bursik MI and Rupp B, 2008. The rain-triggered Atenquique volcaniclastic debris flow of October 16, 1955 at Nevado de Colima Volcano, Mexico. Journal of Volcanology and Geothermal Research 173(1-2): 69-83, DOI 10.1016/j.jvolgeores.2007.12.045.

Schneuwly D, Stoffel M and Bollschweiler M, 2009a. Formation and spread of callus tissue and tangencial rows of resin ducts in Larix decidua and Picea abies following rockfall impacts. Tree Physiology 29: 281-289, DOI 10.1093/treephys/tpn026.

Schneuwly D, Stoffel M, Dorren LKA and Berger F, 2009b. Threedimentional analysis of anatomical growth response of Europan conifers to mechanical disturbance. Tree Physiology 29: 12471257, DOI 10.1093/treephys/tpp056.

Schneuwly-Bollschweiler M and Stoffel M, 2012. Hydrometeorological triggers of periglacial debris flows in the Zermatt valley (Switzerland) since 1864. Journal of Geophysical Research 117: 1-12, DOI 10.1029/2011JF002262.

Schraml K, Kogelnig-Mayer B, Scheidl C, Stoffel M and Kaitna R, 2013. Estimation of debris flood magnitudes based on dendrogeomorphic data and semi-empirical relationships. Geomorphology 201: 80-85, DOI 10.1016/j.geomorph.2013.06.009.

Schraml K, Oismüller M, Stoffel M, Hübl J and Kaitna R, 2015. Debrisflow activity in five adjacent gullies in a limestone mountain range. Geochronometria 42: 60-66, DOI 10.1515/geochr-20150007.

Scott K, Macías JL, Naranjo JA, Rodríguez S, McGeehin JP, 2001. Catastrophic debris flows transformed from landslide in volcanic terrains: mobility, hazard assessment and mitigation strategies. U. S. Geological Survey Professional Paper, 1630.59 p.

Shroder J, 1978. Dendrogeomorphological analysis of mass movement on table cliffs plateau, UTA. Quaternary Research 9: 168-185.

Smith GA and Fritz WJ, 1989. Volcanic influences on terrestrial sedimentation. Geology 17: 375-376, DOI 10.1130/00917613(1989)017<0375:VIOTS >2.3.CO;2.

Stahle D, Villanueva J, Cleaveland MK, Therrell MD, Paull GJ, Burns BT, Salinas W, Suzan H and Fule P, 2000. Recent tree-rings research in Mexico. Dendrogeomorfología en América Latina. F.A. Roig (comp); EDIUVC, Mendoza, Argentina, 285-306.

Stoffel M, 2008. Dating past geomorphic processes with tangencial rows of traumatic resin ducts. Dendrochronologia 26: 53-60, DOI 10.1016/j.dendro.2007.06.002.

Stoffel $\mathrm{M}$ and Beniston M, 2006. On the incidence of debris flows from the early Little Ice Age to a future greenhouse climate: a case study from the Swiss Alps. Geophysical Research Letters 33: 1-4, DOI 10.1029/2006GL026805.

Stoffel M, 2010. Magnitude-frequency relationships of debris flows - a case study based on field surveys and tree-ring records. Geomorphology 116: 67-76, DOI 10.1016/j.geomorph.2009.10.009.
Stoffel M and Bollschweiler M, 2008. Tree-ring analysis in natural hazards research - an overview. Natural Hazards and Earth System Sciences 8: 187-202, DOI:10.5194/nhess-8-187-2008.

Stoffel M, Bollschweiler M and Beniston M, 2011a. Rainfall characteristics for periglacial debris flows in the Swiss Alps: past incidences - potential future evolutions. Climatic Change 105: 263-280, DOI 10.1007/s10584-011-0036-6.

Stoffel M, Bollschweiler M, Butler DR and Luckman BH, 2010. Whither dendrogeomorphology? In: Stoffel, M., Bollschweiler, M., Butler, D. R., Luckman, B. H. (eds.) Tree rings and natural hazards: A state-of-the-art. Springer, Heidelberg, New York, pp. 495-502.

Stoffel M, Bollschweiler M, Vázquez-Selem L, Franco-Ramos O and Palacios D, 2011b. Dendrogeomorphic dating of rockfalls on lowlatitude, high-elevation slopes: Rodadero, Iztaccíhuatl volcano, Mexico. Earth Surface Processes and Landforms 36: 1209-1217, DOI 10.1002/esp.2146.

Stoffel M and Corona C, 2014. Dendroecological dating of geomorphic disturbance in trees. Tree-Ring Research 70(1): 3-20, DOI 10.3959/1536-1098-70.1.3.

Stoffel M and Hitz OM, 2008. Snow avalanche and rockfall impacts leave different anatomical signatures in tree rings of Larix decidua. Tree Physiology 28(11): 1713-1720, DOI 10.1093/treephys/28.11.1713.

Stoffel M, Mendlik T, Schneuwly-Bollschweiler M and Gobiet A, 2014a. Possible impacts of climate change on debris-flow activity in the Swiss Alps. Climatic Change 122: 141-155, DOI 10.1007/s10584-013-0993-z.

Stoffel M, Tiranti D and Huggel C, 2014b. Climate change impacts on mass movements - case studies from the European Alps. Science of the Total Environment 493: 1255-1266, DOI 10.1016/j.scitotenv.2014.02.102.

Stoffel M and Wilford DJ, 2012. Hydrogeomorphic processes and vegetation: disturbance, process histories, dependencies and interactions. Earth Surface Processes and Landforms 37: 9-22, DOI 10.1002/esp. 2163.

Šilhán S and Stoffel M, 2015. Impacts of age-dependent tree sensitivity and dating approaches on dendrogeomorphic time series of landslides. Geomorphology 236: 34-43, $\quad$ DOI 10.1016/j.geomorph.2015.02.003.

Vallance JW, 2005. Volcanic debris flow. In: M. Jakob and O. Hungr (eds). Debris-flows Hazards and Related Phenomena (pp. 247 274). Praxis, Springer. Berlin Heidelberg.

Vallance JW, 2000. Lahars. In: H. Sigurdsson, B. F. Houghton, S. R. McNutt, H. Rymer, and J. Stix (eds). Encyclopedia of volcanoes (pp. 601 - 616). Academic Press, London.

Vallance JW, Schilling SP, Devoli G, Reid ME, Howell MM and Brien DL, 2004. Lahar hazards at Casita and San Cristóbal volcanoes, Nicaragua. U.S Geological Survey. Open-File Report 01-468, 118.

Vázquez R, Capra L, Caballero L, Arámbula-Mendoza R and ReyesDávila G, 2014. The anatomy of a lahar: Deciphering the 15th September 2012 lahar at Volcan de Colima, Mexico. Journal of Volcanology and Geothermal Research 272: 126-136, DOI 10.1016/j.jvolgeores.2013.11.013.

Vázquez-Selem L and Heine K, 2011. Late Quaternary Glaciation in Mexico. In: J. Ehlers, P.L. Gibbard, and P.D. Hughes. (Eds.). Quaternary Glaciations - Extent and Chronology. A closer look. Elsevier, Amsterdam, 849-861.

Villanueva Díaz J, Cerano Paredes J, Stahle DW, Constante García V, Vázquez Selem L, Estrada Avalos J and Benavides Solorio J, 2010. Árboles longevos de México. Revista Mexicana de Ciencias Forestales 1(2): 7-29.

Waldron HH, 1967. Debris flows and erosion control problems caused by the ash eruptions of Irazú volcano, Costa Rica. Geological Survey Bulletin 1241-I: 1-37.

Worni R, Huggel C, Stoffel M and Pulgarin B, 2012. Challenges of modelling recent, very large lahars at Nevado del Huila Volcano, Colombia. Bulletin of Volcanology 74: 309-324, DOI 10.1007/s00445-011-0522-8. 